\title{
Comparative study on the trophic structure, cycling and ecosystem properties of four tidal estuaries
}

\author{
D. Baird ${ }^{1}$, R. E. Ulanowicz ${ }^{2}$ \\ ${ }^{1}$ Department of Zoology, University of Port Elizabeth, PO Box 1600, Port Elizabeth 6000, South Africa \\ ${ }^{2}$ University of Maryland, Cheasapeake Biological Laboratory, PO Box 38, Solomons, Maryland 20688, USA
}

\begin{abstract}
This paper presents results on the comparative ecology of 4 tidal estuaries: the Ythan in Scotland, the Ems-Dollard in The Netherlands and the Swartkops and Kromme estuaries, both located in the Cape Province, South Africa. Flow models (in carbon) were constructed for each of these and analysed by means of network analysis. Specific attention was given to the trophic structure, and to the structure and magnitude of cycling in each estuary. We found that the trophic structure is similar for all 4 estuaries, but that differences exist in the rates of primary production and its utilization, standing stocks, in the systems' trophic efficiencies, and in the detrivory:herbivory ratios. Three aspects of cycling are considered: (1) the number of cycles and their distribution against cycle lengths; (2) the Finn cycling index $(\mathrm{FCl})$ and $(3)$ the whole system average path length (APL). Cycling analysis revealed that the FCI and the APL were highest in the most polluted estuary, the Swartkops, and lower in the other less stressed systerns. The composite cycled flows revealed similar structures with virtually all components participating in the recycling of material in the estuaries. Global system properties such as total system throughput, development capacity, ascendancy, relative ascendancy and indices of flow diversity have also been calculated by means of network analysis. Results show that despite the high productivity, high FCl and longer path length of the Swartkops estuary, it exhibits the lowest relative ascendancy, indicating it to be more impacted than any of the other 3 estuaries.
\end{abstract}

\section{INTRODUCTION}

The functioning of tidal estuaries involves the complex interactions of physical, biogeochemical and biological processes. The measurement of energy and material flows between the various ecosystem components and the efficiency with which energy is assimilated, transferred and dissipated provides significant insight into the fundamental structure and function of the system (Longhurst 1984, Ulanowicz \& Platt 1985. Ulanowicz 1986, Wulff et al. 1989, Baird et al. 1991). Recently network analysis, which includes input-output, trophic and cycling analysis and the calculation of ecosystem indices such as Total System Throughput, Development Capacity, Ascendancy and System Overhead, has been used to examine, for example, the seasonal dynamics of Chesapeake Bay (Baird \&
Ulanowicz 1989), the North Inlet saltmarsh ecosystem (Asmus \& McKellar 1989), seasonal changes in an estuarine benthic community (Warwick \& Radford 1989), open ocean plankton systems (Ducklow et al. 1989), and the successive stages after the development of an upwelling event (Field et al. 1989a). It has also been used to compare ecosystems of different sizes, geographical location and complexity (Baird et al. 1991, Ulanowicz \& Wulff 1991). The aim of this paper is to examine and compare some functional processes and global ecosystem attributes of 4 tidal estuaries: 2 from the Northern and 2 from the Southern Hemisphere. We present results specifically on the energy flow networks, the trophic analysis, the structure and magnitude of the cycling of material in each of the 4 estuaries, and on system quantities representative of the status of each system's development. To compare the 
results of different estuarine ecosystems, 2 important criteria must be satisfied: firstly, the topology, flow structure and degree of aggregation among the living components must be essentially the same; and secondly, the same medium or currency must be used for all systems. In this study all flow networks were aggregated into 14 to 16 compartments, and carbon (C) was used as the currency.

This comparative study examines flow networks by means of network analysis which includes inputoutput flow analysis (Leontief 1951, Hannon 1973), cycling (Finn 1976), through-flows, storages and information theory (Ulanowicz 1986, Field et al. 1989b) and thus offers formal methods for analysing ecosystem structure. Detailed reference to the underlying theoretical concepts and methodology of network analysis is given by Ulanowicz (1986) and Kay et al. (1989). Total system properties used in this paper are: total system throughput ( $T$ ), reflecting the size of the system in terms of the sum of flows through all the individual compartments; ascendancy $(A)$, which represents both the size and the organization of the flows; and the development capacity $(C)$, the natural upper limit to ascendancy. The degree of a system's realized growth, organization and development can be given by the A/C ratio (Ulanowicz \& Mann 1981). Highly organized systems have the tendency to internalize most of their activity and exchanges and become relatively independent of external inflows and outflows. The ratio of the internal indices of $A_{i}$ and $C_{i}\left(A_{i} / C_{i}\right.$ ratio $)$ is considered to be representative of a system's development status (Field et al. 1989a, Mann et al. 1989, Baird et al. 1991). This ratio appears to be high in well organized systems possessing significant internal stability which makes it difficult for a new influences to change its basic structure, and lower in systems under stress.

\section{STUDY AREAS}

The 4 estuaries examined in this study have several features in common. They are all tidally dominated, have extensive intertidal flats and salt marshes, and exhibit salinity gradients (with the exception of one, the Kromme estuary) from the tidal inlets to the upper reaches. They differ, however, in some respects. Two of the systems examined, namely the Swartkops and Ythan estuaries, are mildly polluted through inputs of agricultural, industrial and sewage effluents (Baird \& Milne 1981, Lord \& Thompson 1988). The Kromme estuary represents a fairly pristine system, in that the river drains a forested catchment area in which little or no agricultural or industrial activity takes place (Baird \& Pereyra-Lago 1992). It is subject, however, to reduced freshwater inflow due to 2 large impoundments in the catchment, which result in a homogeneous saline (32 to $35 \mathrm{ppt}$ ) estuarine water body (Anon. 1991). The Ems estuary is rich in pelagic and benthic life and there is little evidence of eutrophication or pollution despite its carrying a quantity of nutrients (mainly phosphorus and nitrogen) from the catchment to the sea (Anon. 1985). The data (on standing stocks, flows and energetics of the various species and communities) used to construct the flow networks for each of the systems and on which the analyses are based were obtained from the literature.

The Swartkops estuary $\left(32^{\circ} 52^{\prime} \mathrm{S}, 25^{\circ} 39^{\prime} \mathrm{E}\right)$ is 10 cated on the southeast coast of southern Africa, near Port Elizabeth, and discharges into the Indian Ocean through a constricted but permanently open inlet. The estuary was formed during the sea level rise after the Pleistocene, and its present configuration is the result of sediment fill (Reddering \& Esterhuysen 1981). The present flood plain and river bed of the Swartkops estuary were formed subsequent to the Flandrian Transgression (12000 to $4000 \mathrm{yr}$ B.P.) when the mean sea level (MSL) regressed from about MSL $+3 \mathrm{~m}$ to the present level of MSL $+0 \mathrm{~m}$. The general morphology of the estuary was laid down during the period $4000 \mathrm{yr}$ to present. The sediment of the lower reaches and mouth regions of the estuary consists mainly of coarse sand of marine origin, whereas the sediments of the middle and upper reaches are composed of fine grained sand and mud of fluvial origin (Reddering \& Esterhuysen 1981). The tidal range at the inlet is $1.6 \mathrm{~m}$ but decreases up estuary. The average tidal prism of the estuary is ca $2.88 \times 10^{6} \mathrm{~m}^{3}$ in volume and the flushing time is ca $22 \mathrm{~h}$ at spring tide. Sediment materials are resuspended due to the relatively fast currents during flood and ebb tides (Winter \& Baird 1991). The Swartkops estuary is a small, shallow, temperate, turbid, wellmixed estuary (Baird \& Winter 1989) which attracts many migrating Palearctic birds (Martin \& Baird 1987) and is a popular recreational area for boating, angling and swimming. The river and its estuary flow through heavily populated urban areas, and are subject to agricultural and industrial pollution (Emmerson 1985, Lord $\&$ Thompson 1988). The data for the construction of an energy flow network for this estuary were obtained from Hanekom (1980), Marais \& Baird (1980a, b), Mellville-Smith \& Baird (1980), Pierce (1983), Marais (1984, 1987), Talbot \& Baird (1985), Baird et al. (1986, 1988), Martin \& Baird (1987), Baird (1988), Hanekom et al. (1988), Hilmer et al. (1988), Martin (1991), and Hanekom \& Baird (1992). The salinity ranges from $35 \mathrm{ppt}$ at the mouth to about $10 \mathrm{ppt}$ at the head, and the water temperature varies from $28^{\circ} \mathrm{C}$ in summer to $13.5^{\circ} \mathrm{C}$ in winter. The estuary is about $15 \mathrm{~km}$ long and has a total surface area of about $4 \mathrm{~km}^{2}$ including an. intertidal area of $3.63 \mathrm{~km}^{2}$ composed of sand and mud- 
flats $\left(1.81 \mathrm{~km}^{2}\right)$ and Spartina maritima dominated salt marshes $\left(1.82 \mathrm{~km}^{2}\right)$

The Kromme estuary $\left(34^{\circ} 08^{\prime} \mathrm{S}, 24^{\circ} 51^{\prime} \mathrm{E}\right)$ discharges into St. Francis Bay, in the Indian Ocean, through a constricted permanently open inlet. The valley of the Kromme River was initially incised during the Tertiary. Its base was further eroded during the Pleistocene Ice Age (1.5 million to 12000 yr B.P.), but was subsequently drowned and filled with fluvial sediments when the sea level rose by $3 \mathrm{~m}$ above MSL during the Flandrian Transgression, 12000 to 4000 yr B.P. The present configuration of the estuary has taken shape during the period of retreat from its high Holocene (Flandrian) level to the present level during the past 4000 yr (Fromme \& Badenhorst 1987). The sediments in the lower and mouth reaches of the estuary consist mainly of sand grains of marine origin, whilst organic rich muddy substrates of fluvial origin are distinctive of the middle and upper reaches of the estuary (Baird et al. 1992)

The Kromme estuary is shallow [average depth at low water spring tide (LWST) of $2.5 \mathrm{~m}$ ), well mixed, and about $14 \mathrm{~km}$ long with a total surface area of about $3 \mathrm{~km}^{2}$. The tidal prism and flushing time during spring tides are on average $1.87 \times 10^{6} \mathrm{~m}^{3}$ in volume and $26 \mathrm{~h}$ respectively. The tidal amplitude is $1.6 \mathrm{~m}$ at the tidal inlet but decreases upstream. The intertidal area of ca $1.4 \mathrm{~km}^{2}$ consists of a salt marsh of about $0.8 \mathrm{~km}^{2}$ which is dominated by the halophyte Spartina maritima, and $0.6 \mathrm{~km}^{2}$ of mud and sand flats. Dense beds of eel grass Zostera capensis occur inter- and subtidally all along the estuary. The river and estuary flow through a sparsely populated area, with no industries and little agricultural activity along its banks (Bickerton \& Pierce 1988). The temperature fluctuates between $11.7^{\circ} \mathrm{C}$ in winter and $28.0^{\circ} \mathrm{C}$ in summer, while the salinity has rarely dropped below $32 \mathrm{ppt}$ during the past $10 \mathrm{yr}$. Studies on the water quality of this estuary were conducted by Emmerson \& Erasmus (1987) and Baird \& Pereyra-Lago (1992). Data for the flow network were obtained from Hecht (1973), Baird et al. (1981), Hanekom (1982), Marais (1983, 1984, 1987), Hanekom \& Baird (1984, 1988), Bickerton \& Pierce (1988), and Heymans \& Baird $(1991,1992)$.

The Ythan estuary $\left(20^{\circ} 00^{\prime} \mathrm{W}, 57^{\circ} 20^{\prime} \mathrm{N}\right)$, located about $20 \mathrm{~km}$ north north of Aberdeen, Scotland, is a drowned river valley which reached its present morphology subsequent to the post-Holocene sea level rise (Raffaelli 1992). The surface area of the of the estuary is about 256 ha, with an intertidal area of about 185 ha. The substrate in the mouth and lower reaches consists mainly of sand, with the rest of the estuarine substrates composed mainly of mud and a mud-sand mixture. The mean flushing time of ca $15 \mathrm{~h}$ is relatively brief because of the strong tidal currents and small vol- ume of freshwater drainage. The water volume of the estuary at LWST is $3.8 \times 10^{5} \mathrm{~m}^{3}$ and $3.8 \times 10^{6} \mathrm{~m}^{3}$ at high water spring tide (HWST) (Baird \& Milne 1981).

The estuary is tidal for about $8 \mathrm{~km}$ from the mouth and receives about $2000 \mathrm{~m}^{3}$ of primary treated sewage per day from upstream towns. The salinity ranges from $5 \mathrm{ppt}$ at the head to $35 \mathrm{ppt}$ at the mouth, whilst the temperature fluctuates from about $3^{\circ} \mathrm{C}$ during winter to $20^{\circ} \mathrm{C}$ in summer. The tidal characteristics and detailed information on the standing stocks and energy flow between the various biotic components can be found in Baird \& Milne (1981)

The Ems estuary $\left(6^{\circ} 54^{\prime} \mathrm{E}, 53^{\circ} 26^{\prime} \mathrm{N}\right)$ is a shallow semi-diurnal tidal estuary draining into the Wadden Sea. The Wadden Sea and its estuaries originated from the last 2 glaciations. The shape of the Ems estuary was formed during the Pleistocene by the combined effects of sediment supply, a high tidal range and storm surges. A number of storm surges changed the original funnel shape of the Ems estuary drastically and enlarged it considerably (De Jonge 1988).

The sediments in the mouth region consist of sand, whereas the clay content increases in the middle and upper reaches of the estuary. The composition of the sediments remained conservative over the last few centuaries (De Jonge 1988)

Freshwater runoff in the estuary is variable, ranging from $1.2 \times 10^{10} \mathrm{~m}^{3}$ to $7.9 \times 10^{8} \mathrm{~m}^{3}$ anually. The tidal amplitude is $2.20 \mathrm{~m}$ near the mouth but increases upstream to $3.03 \mathrm{~m}$ about $35 \mathrm{~km}$ from the inlet. Due to the asymmetry in the tidal currents, i.e. currents of higher velocities during flood than ebb tides, and drift currents, deposition and resuspension of sediment particles are common phenomena in the Ems estuary. Low density particles in suspension are exported to the sea while for heavier particles a net import can occur (De Jonge 1988). The tidal prism at the inlet is ca $900 \times$ $10^{6} \mathrm{~m}^{3}$, and the flushing time of the water in the estuary varies between 12.1 and $72.1 \mathrm{~d}$ at low and high freshwater discharge rates respectively (De Jonge 1988)

The Ems estuary contains large tidal flats of about $245.7 \mathrm{~km}^{2}$ and has a total area of about $500 \mathrm{~km}^{2}$; it is thus the largest of the 4 estuaries studied in this paper. It is rich in benthic and pelagic life and although it receives large amounts of nutrients annually from both the sea and the catchment, there is little evidence of eutrophication or pollution (Anon. 1985, De Jonge 1988). The water temperature ranges from 4 to $20^{\circ} \mathrm{C}$, and the salinity from $34 \mathrm{ppt}$ in the Wadden Sea to $14 \mathrm{ppt}$ in the upper reaches. The chemical, physical and biological properties of the Ems estuary have been documented in detail by Anon. (1985) and Baretta \& Ruardij (1988). They and Baird et al. (1991) provide the necessary information on standing stocks, flows and 
energetics of the various biotic components on which the flow model of the Ems estuary is based.

\section{MATERIALS AND METHODS}

Carbon flow networks were constructed for each of the estuaries described above. The networks illustrate the standing stocks of the various living and non-living components in $\mathrm{mg} \mathrm{C} \mathrm{m} \mathrm{m}^{-2}$ and the flows between the compartments in $\mathrm{mg} \mathrm{C} \mathrm{m} \mathrm{m}^{-2} \mathrm{~d}^{-1}$ For heterotrophs the carbon uptake $\left(\mathrm{C}_{u}\right)$ by each living compartment was balanced by production (P), respiration (R) and excreta (E). For primary producers, phytoplankton and benthic algae, gross primary production (GPP) was assumed equal to the sum of net primary production (NPP) plus respiration ( $R$ ). The values for GPP were used as inputs into each system. Exudation by primary producers is considered to be the largest source of disolved organic carbon (DOC) (Valiela 1984). Estimates of DOC exudation by phytoplankton cells range from 5 to $50 \%$ of net photosynthate (Fogg et al. 1965, Valiela 1984, Vegter \& de Visscher 1984) and between 1 and $60 \%$ by macroalgae (Sieburth \& Jensen 1969, Brylinsky 1977. Hatcher et al. 1977, Linley et al. 1981). We have assumed a constant DOC loss of $25 \%$ of the net production (Baird \& Ulanowicz 1989) which is in turn taken up by free-living bacteria (Wiebe \& Smith 1977, Azam et al. 1983, Ducklow 1983, Findlay et al. 1986). System outputs consisted of respiration, exports in the form of suspended material and emigration of birds and fish. The production of compartments (e.g. birds and fish) not utilized in the food webs or recycled was assumed to be exported from each system. The systems were also assumed to be in a steady state, thus the annually averaged inputs were balanced by the corresponding outputs for each compartment. Biomass, the diet composition of the various consumers, rates of consumption, production and respiration of the different trophic groups or species were obtained from the relevant literature or calculated using appropriate ecological efficiencies such as $\mathrm{P} / \mathrm{B}, \mathrm{P} / \mathrm{C}_{\mathrm{u}}$ and $\mathrm{P} / \mathrm{R}$ ratios. Ecosystem comparisons are complicated by having compartments with different degrees of aggregation (Mann et al. 1989, Baird et al. 1991). To overcome this, species having the same mode of feeding and which obtain their food from common prey sources were grouped together into their respective model compartments. For example, all the fish species feeding mainly on benthic organisms were grouped together as benthic feeding fish. Similarly, benthic suspension (or filter) feeders and deposit feeders (or detritivores) (compartments common to all 4 systems) comprised macro-invertebrate species obtaining nourishment from the water column and from benthic algae and sediment detritus, respectively. The pelagic plankton components of each system were grouped in the same way, based mainly on size and mode of feeding. Free-living pelagic bacteria occur in a single compartment, whilst heterotrophic microflagellates and microzooplankton (including taxa such as rotifers, sarcodinians, copepod nauplii stages, etc.) were grouped together in another compartment. The mesozooplankton compartment consists of zooplankton organisms feeding predominantly on phytoplankton. Not all compartments are represented in each system due to the different biological composition of the different estuaries. A second criterion for ecosystem comparisons is that the topology of the network should be consistent from one system to the other. The network structures consist of 14 to 16 compartments, including 3 non-living components, namely suspended particulate organic carbon (POC), sediment POC and DOC. Attached bacteria are included in both suspended and sediment POC. All networks contain 2 primary producer compartments, phytoplankton (pelagic producers) and benthic producers, consisting of benthic macro- and microalgae. In the Kromme estuary, phytobenthos was separated in 2 compartments because of the overwhelming standing crop and production of eelgrass Zostera capensis compared to other primary producers in that system. The networks furthermore contained compartments for pelagic (or freeliving) bacteria $(\leq 2 \mu \mathrm{m})$, microzooplankton (2 to 200 $\mu \mathrm{m})$, mesozooplankton $(\geq 200 \mu \mathrm{m})$, suspension feeders meiofauna, benthic detrivores, several fish groups, and birds. The Kromme estuary has very few migratory or resident birds, and this component was subsequently omitted. The same currency, carbon, was used for biomass and flows in each network. The trophic and cycling structure of each network was analysed and the system properties calculated by algorithms described by Ulanowicz $(1983,1986)$ and Kay et al. (1989). The following information and indices were obtained from the analyses:

1. Contribution coefficients, which give the fractions a particular component in the food network contributed to the 'diets' of other components. This analysis defines the 'extended diet' of a species in question and yields information on the degree to which the diet of any particular component depends directly and indirectly upon the production of any other member of the ecosystem.

2. The effective or average trophic status for each component or species in the food network. The effective trophic position refers to the weighted average number of trophic steps that separate a living component from the primary producers or non-living component in the system, and thus allows the comparison of trophic positions of similar species in different ecosystems. 
3. The mapping of a complex network of trophic transfers into a linear food chain, the Lindeman spine, with discrete trophic levels. The Lindeman spine illustrates the net amount each trophic level receives from the preceding one, as well as the amounts it creates through respiration, exports, detritus for recycling, and net production for transport to the next level. Autotrophs and the non-living organic detrital pool are assigned to the first trophic level. The Lindeman spine also allows the calculation of the trophic efficiency of each level and for the food web as a whole.

4. The Finn cycling index (FCI), which gives the proportion of the flow in a system that is recycled compared with the total system throughput ( $T$; Finn 1976). FCI is thus equal to $T_{C} / T$, where $T_{C}$ is the amount of system activity devoted to cycling. FCI measures the retentiveness of a system; the higher the index, the greater the proportion recycled and the more mature or less stressed the system (Odum 1969). An individual cycle represents a unique pathway which begins and ends in the same compartment, and a collection of cycles having the same smallest transfer is called a nexus (Baird et al. 1991).

5. The average path length (APL) measures the average number of transfers a unit of flux will experience from its entry into the system until it leaves the system. This index is derived from APL $=(T-Z) / Z$ where $Z$ is the sum of all exogenous inputs.

6. We consider several global measurements of ecosystem organisation such as: (i) Total system throughput $(T)$, which measures the extent of the total activity transpiring in the system. This is usually measured as the sum of all flows through all compartments in the system. In one sense, $T$ is a surrogate for the total power generated within the system (Odum 1971). (ii) Network ascendancy (A) which incorporates both the size and organization of flows into a single measure. Formally, it is expressed as the product of $T$ and the mutual information inherent in the flow network. According to Ulanowicz (1986) the ascendancy of a system should increase as it matures through a series of development stages. (iii) Development capacity (C) which measures the potential for a system to develop. It can be demonstrated that $C$ is the natural upper limit of $A$. Both the ascendancy and the capacity will decrease if a system is affected by disturbance or pollution stress. (iv) System overhead ( $\Phi$ ), numerically represented as the difference $C-A$. (v) The internal ascendency $\left(A_{1}\right)$ and internal development capacity $\left(C_{\mathrm{i}}\right)$ by which are meant those components of the ascendancy and the capacity, respectively, that are composed solely of the internal exchanges (and thus excludes exogenous transfers into and out of the system) (Ulanowicz 1986, Kay et al. 1989, Ulanowicz \& Norden 1990, Baird et al, 1991) [C, $A$ and $R$ are expressed as 'bits', which refers to the log (base 2) used in the formulae to calculate these quantities]

\section{RESULTS}

\section{Ecosystem flow networks and trophic structure}

The carbon flow networks for each of the systems are illustrated in Figs. 1 to 4. The Ems and Swartkops estuaries consist of 15 compartments each (Figs. 1 \& 3), the Ythan estuary (Fig. 2) 14 compartments, and the Kromme estuary 16 compartments (Fig. 4). The reason for the one extra compartment in the Kromme network is due to the separation of the benthic producers into macrophytes (Compartment 2) and benthic microalgae (mainly diatoms, Compartment 3, Fig. 4). The Ythan network has one less than the Ems and Swartkops estuaries, because the fish component (Compartment 10, Fig. 4) consists mainly of benthicfeeding fish. The fish component (Compartment 11 Fig. 1) in the Ems estuary similarly consists of mainly benthic feeders. The ubiquitous family Mugilidae (Pisces) was separated from other benthic-feeding fish in the Kromme estuary (Compartment 13, Fig. 4) due to their smaller size and mode of feeding; they feed exclusively on sediment bacteria and microalgae (Mason \& Marais 1975). Despite these small differences in network structure, it was noted that if all networks were structured in a 14-compartment configuration, the effect on system parameters ( $T, A$ and $C$ ) was negligible Some characteristics of each estuary are given in Table 1.

Of interest is the variability in the standing crop and rate of primary production between the 4 ecosystems (see Figs. 1 to 4). The Kromme estuary exhibits the highest rate of primary production $\left(2312 \mathrm{mg} \mathrm{C} \mathrm{m}^{-2}\right.$ $\mathrm{d}^{-1}$ ), with the Ythan and Swartkops estuaries very

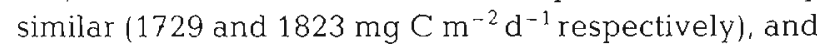
the Ems estuary the lowest (203 $\mathrm{mg} \mathrm{C} \mathrm{m} \mathrm{m}^{-2} \mathrm{~d}^{-1}$ ). Phytoplankton production in the Kromme estuary is, however, exceptionally low (28.3 $\mathrm{mg} \mathrm{C} \mathrm{m}^{-2} \mathrm{~d}^{-1}$ ) when compared to the other estuaries, which can be ascribed to the low dissolved inorganic nitrogen and phosphorus levels in this estuary (Baird \& Pereyra-Lago 1992). On the other hand, macrophyte production (2086 $\mathrm{mg} \mathrm{C} \mathrm{m} \mathrm{m}^{-2} \mathrm{~d}^{-1}$ ), in particular that of eelgrass Zostera capensis, is higher than in any of the other systems (Hanekom \& Baird 1988). The net primary production in all 4 estuaries is dominated by phytobenthic production, with the exception of the Ems estuary where the ratio of pelagic phytoplankton production to benthic primary production is $1: 1.04$, whereas this ratio in the other estuaries is $1:>5$. This ratio is especially high in the Kromme estuary (1:80). The total 


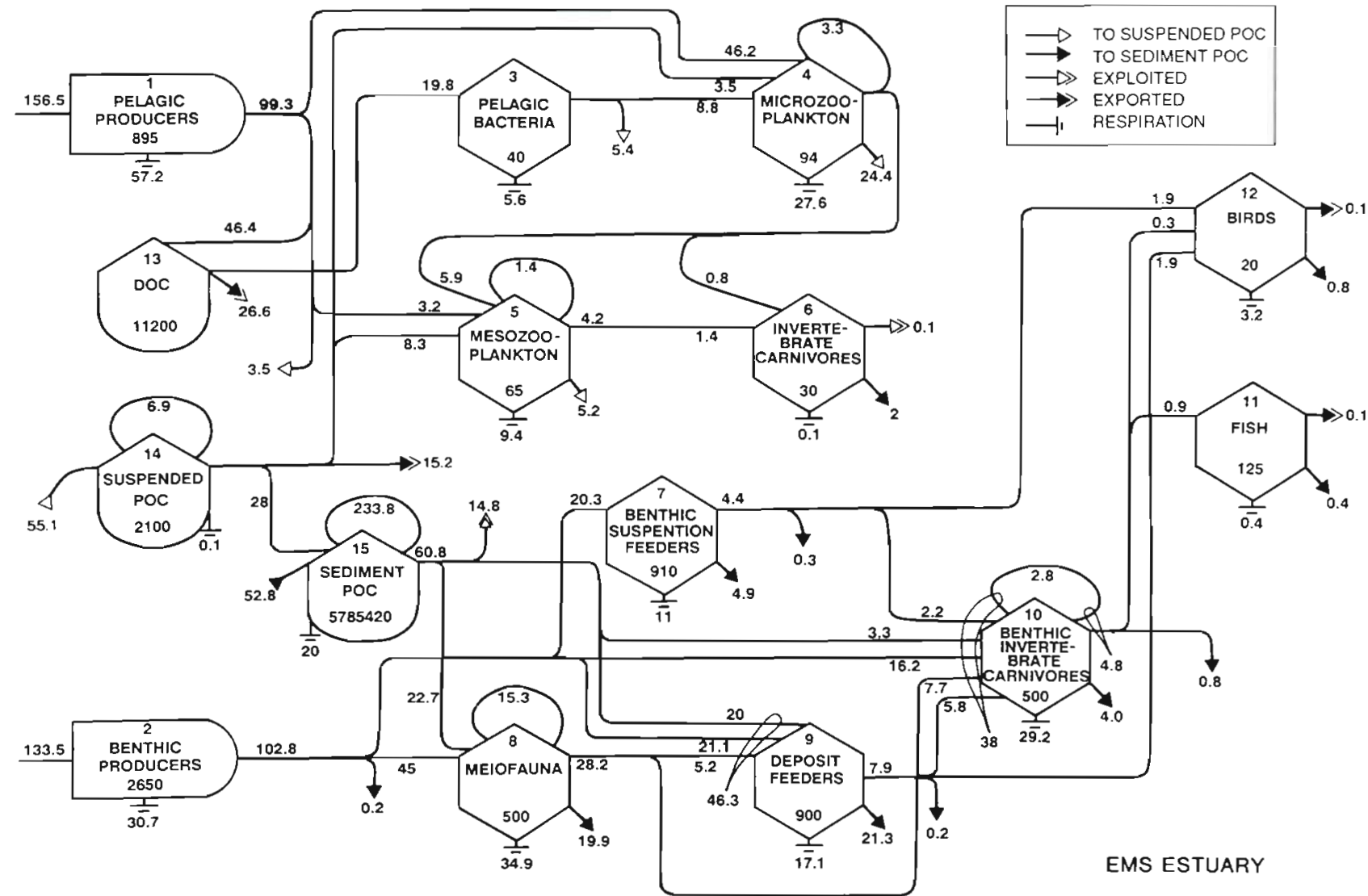

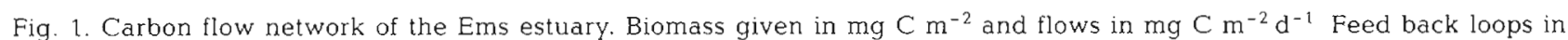
Compartments $4,5,8,10,14 \& 15$ indicate the feeding of some species on others within the same compartment.

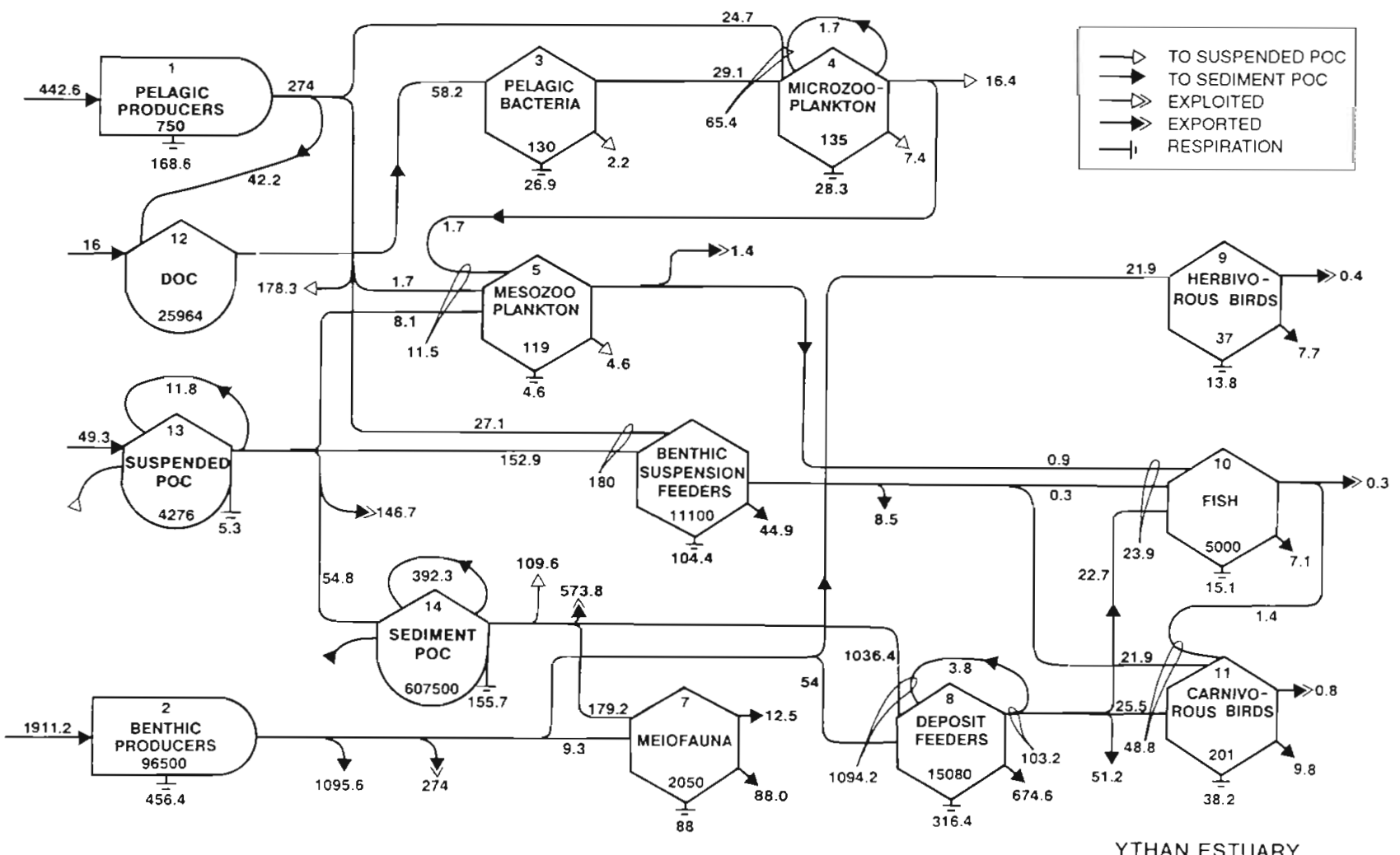

Fig. 2. As in Fig. 1 but for the Ythan estuary. Note feed back loops in Compartments $4,8,13$ \& 14 


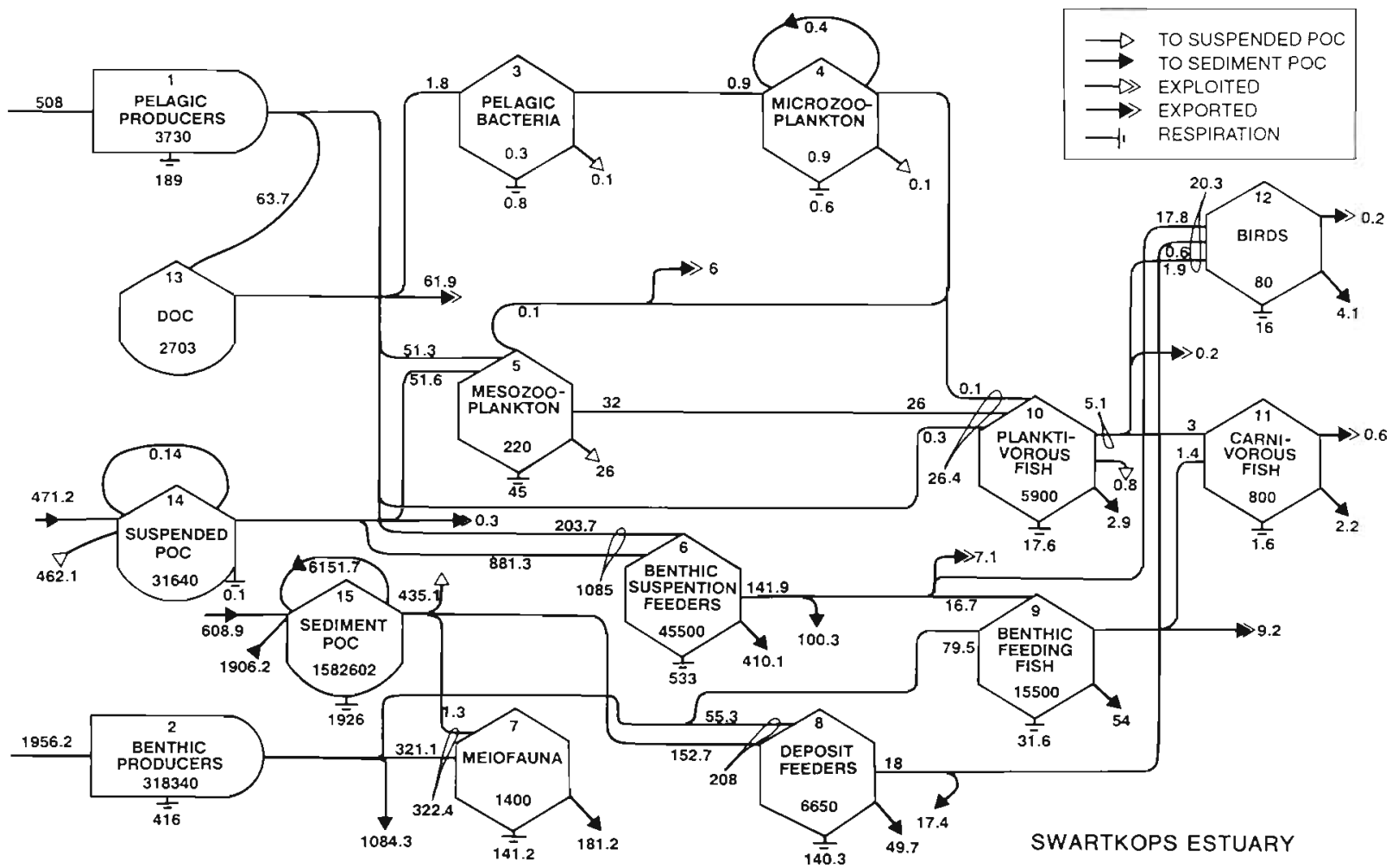

Fig. 3. As in Fig. 1 but for the Swartkops estuary. Note feed back loops in Compartments 4, 14 \& 15

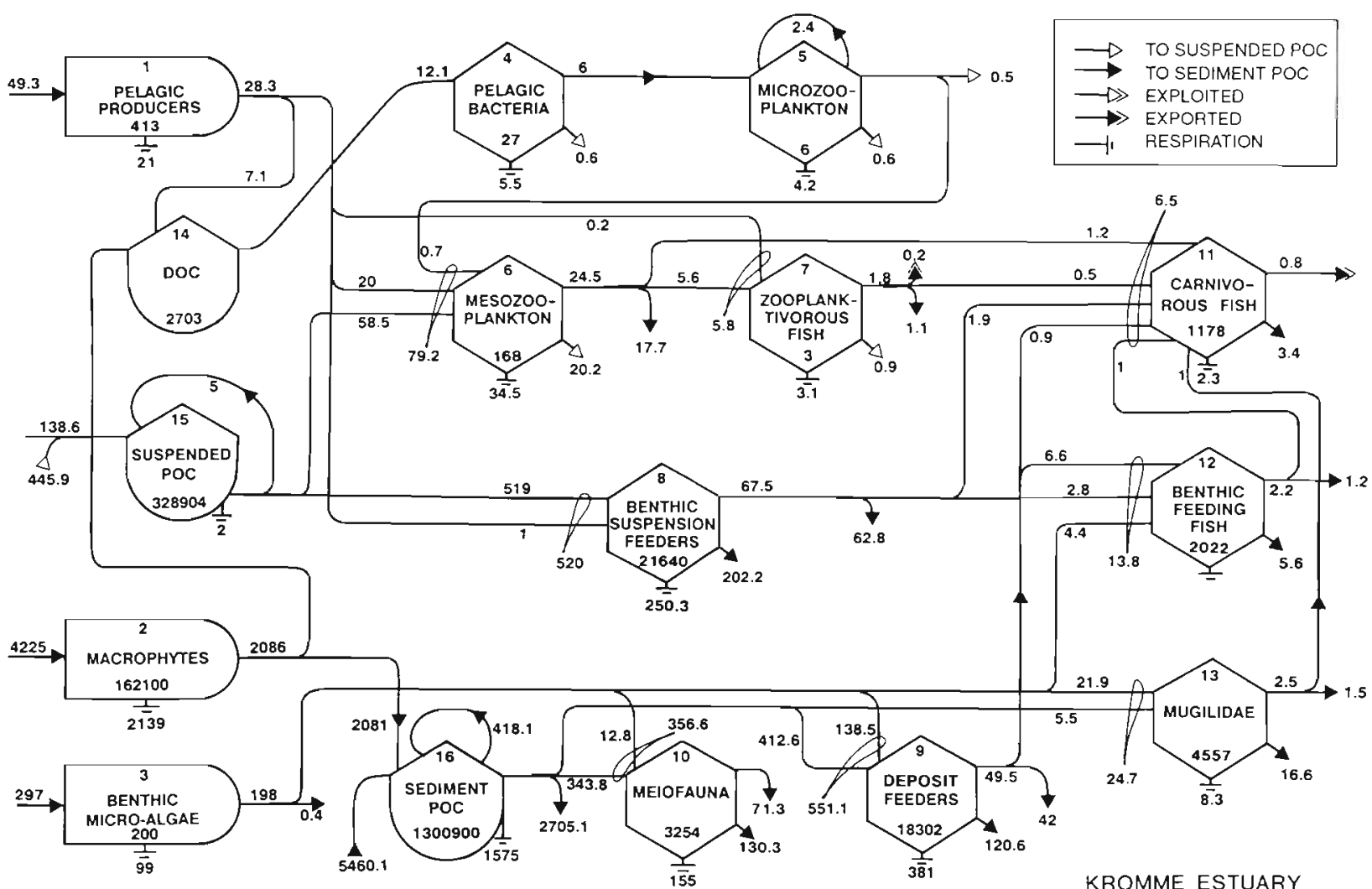

Fig. 4. As in Fig. 1 but for the Kromme estuary. Note feed back loops in Compartments 4, 15 \& 16 
Table 1. Properties of the Ythan, Swartkops, Kromme and Ems estuaries

\begin{tabular}{|c|c|c|c|c|}
\hline Attribute & Ythan & Swartkops & Kromme & Ems \\
\hline Area $\left(\mathrm{km}^{2}\right)$ & 2.4 & 4.0 & 3.0 & 500 \\
\hline Temperature range $\left({ }^{\circ} \mathrm{C}\right)$ & $5-15$ & $13-26$ & $13-28$ & $4-20$ \\
\hline Salinity (ppt) & $15-35$ & $10-35$ & $33-35$ & $14-34$ \\
\hline No. of model compartments & 14 & 15 & 16 & 15 \\
\hline $\begin{array}{l}\text { Net primary production } \\
\left(\mathrm{mg} \mathrm{C} \mathrm{m} \mathrm{m}^{-2} \mathrm{~d}^{-1}\right)\end{array}$ & 1729 & 1823 & 2312 & 203 \\
\hline $\begin{array}{l}\text { Total standing stock } \\
\left(\mathrm{g} C \mathrm{~m}^{-2}\right)\end{array}$ & 131.1 & 398.1 & 213.9 & 6.7 \\
\hline $\begin{array}{l}\text { Total production } \\
\text { (primary and secondary, } \mathrm{mg} \mathrm{C} \mathrm{m}^{-2} \mathrm{~d}^{-1} \text { ) }\end{array}$ & 1926.6 & 3981.0 & 327.9 & 268.0 \\
\hline NPP efficiency (\%) & 10.5 & 38.0 & 9.2 & 98.0 \\
\hline Detrivory : herbivory ratio & $10: 1$ & $1.5: 1$ & $6.7: 1$ & $0.5: 1$ \\
\hline
\end{tabular}

Table 2. Trophic position of species or species groups in each ecosystem (numbers in brackets refer to compartment numbers in Figs. 2 to 5 )

\begin{tabular}{|lcccc|}
\hline $\begin{array}{l}\text { Trophic } \\
\text { position }\end{array}$ & Ythan & Swartkops & Kromme & Ems \\
\hline 1 & $1,2,14,15$ & $1,2,14,15$ & $1,2,15,16$ & $1,2,14,15$ \\
$2.0-2.19$ & $5,6,7,8$ & $3,4,7,8,9$ & $4,8,9,10,13$ & $3,6,7,8,9$ \\
$2.2-2.39$ & & 5 & 6 & 5 \\
$2.4-2.59$ & & 10 & & 4 \\
$2.6-2.79$ & 4,9 & & 12 & \\
$2.8-2.99$ & 10 & & 7 & \\
$3.0-2.19$ & 12 & 12 & 5,11 & 10,11 \\
$3.2-2.39$ & & 6 & & \\
$3.4-3.59$ & & 11 & & \\
$3.6-3.79$ & 11 & & & \\
$3.8-3.99$ & & & & \\
\hline
\end{tabular}

standing crop (i.e. the sum of the biomass of all living components) also differs markedly between the 4 systems. The standing stocks of the Swartkops (398.1 $\mathrm{mg} \mathrm{C} \mathrm{m}^{-2}$ ) and the Kromme estuary $(213.9 \mathrm{mg} \mathrm{C}$ $\mathrm{m}^{-2}$ ) are much higher than those of the Ythan (131.1 $\left.\mathrm{mg} \mathrm{C} \mathrm{m}^{-2}\right)$ and the Ems estuary $\left(6.7 \mathrm{mg} \mathrm{C} \mathrm{m}{ }^{-2}\right)$. The differences in production and standing stocks between the systems may be due to the strong seasonal variability in the temperature experienced by the Ythan and Ems estuaries compared to the more temperate southern hemisphere estuaries. The difference in system activity is also reflected in the values of the total system throughput, $T$ (see Table 4). Of equal interest is the range of net primary production (NPP) consumption efficiencies, i.e. the ratio between NPP and herbivore consumption. This ratio is relatively high for the Ems and Swartkops estuaries, but relatively low in the Ythan and Kromme estuaries (Table 1). The effective trophic position of the living components in each of the 4 estuaries is shown in Table 2 . In all the systems, consumer species occupy the second and third trophic levels. The top carnivores in the Swartkops and Ems estuaries appear to feed at slightly higher trophic levels than their counterparts in the other 2 systems (Table 2). This can be ascribed to the fact that carnivorous fish in the Ythan and Kromme estuaries (Compartment 11 in Figs. $4 \& 5$ respectively) obtain more of their sustenance indirectly through suspended and sedimentary POC and benthic primary producers at trophic level 1 , than the top predators in the other 2 estuaries. The energy flow networks were mapped into simplified Lindemann spines, together with their associated routes of recycling (Fig. 5) (Ulanowicz 1986, Baird \& Ulanowicz 1989, Baird et al. 1991). The detrital pool (D) is merged with the primary producers (I) to represent the first trophic level. Detrital returns from all other levels are indicated as well as the loop of detritus contribution from plants and the utilization of the organic material by microorganisms. Respiration and exports from each level are also shown. Trophic efficiencies, given as percentages in the boxes, are defined as that fraction of the total carbon input into a trophic level which is transmitted to the next one. The number of trophic levels varies from 5 in the Ems estuary to 6 in the other 3 systems. The trophic efficiencies generally decrease with ascending levels, although the efficiency at the fifth trophic level in the Swartkops, Kromme and Ythan estuaries is unexpectedly higher than at the preceding one. This feature is especially pronounced in the Kromme and Ythan estuaries, which means that these systems are quite effective in delivering resources to the higher trophic components despite their relatively poor performance over the first 

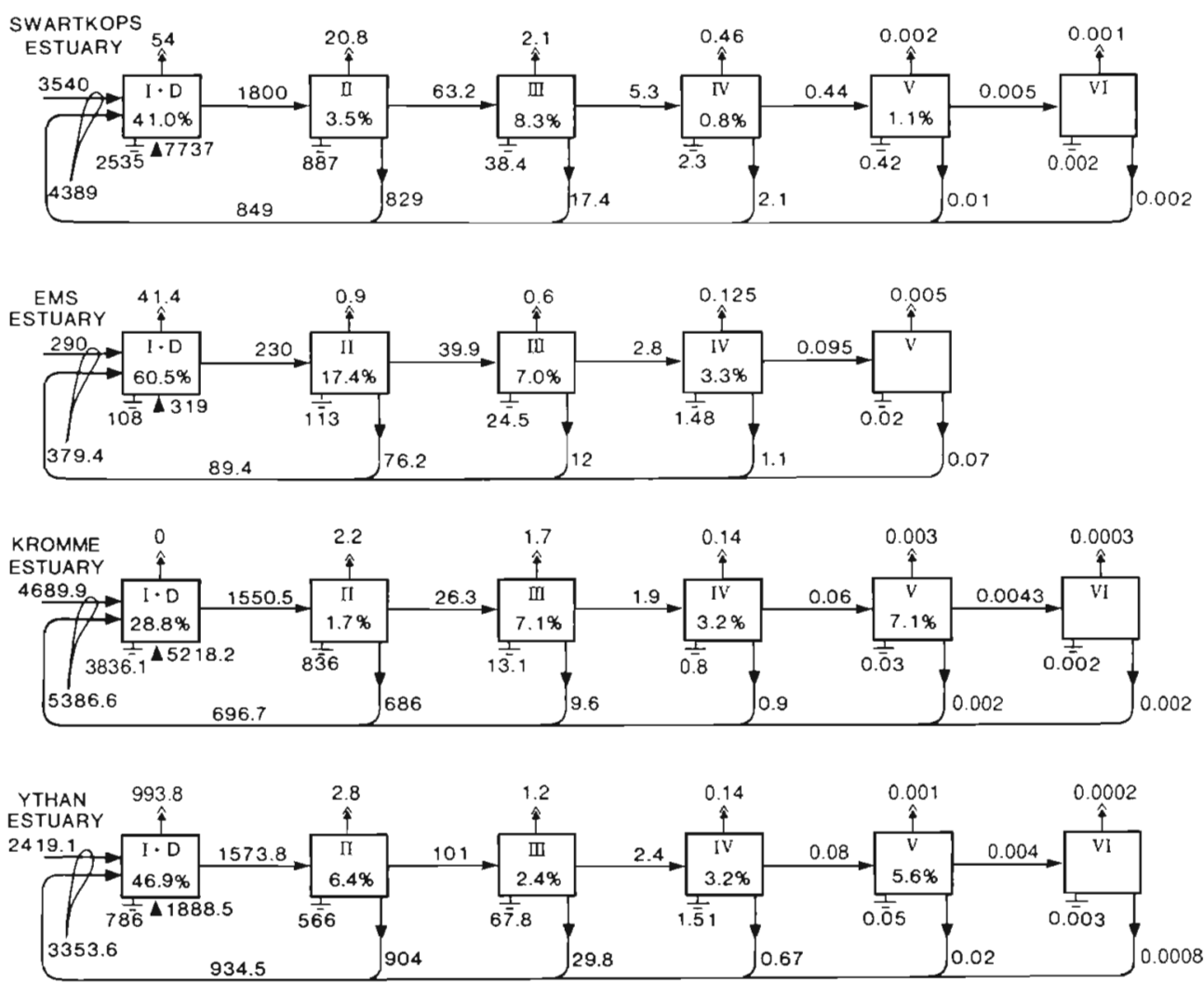

Fig. 5. The Lindeman Spine. The aggregation of the flow networks in Figs. 1 to 4 into a concatenated chain of transfers through trophic levels for each system. The primary producers and detritus compartments are merged in the first trophic level. The per centages in the boxes represent the daily trophic efficiencies. Symbols as in Figs. 1 to 4

few transfers. The efficiencies at the highest trophic levels can be ascribed to the feeding activities of birds on planktivorous fish in the Swartkops estuary (Martin 1991), the predation of carnivorous birds on fish in the Ythan (Baird \& Milne 1981), and the predation of carnivorous fish on benthic feeding fish and on species of the Mugilidae in the Kromme estuary (Marais 1984). The results of the Lindeman Spine analysis indicate that the efficiency at the first trophic level is the highest in the Ems estuary (60\%) and the lowest in the Kromme estuary $(28.8 \%)$, whilst the efficiencies for the Ythan and Swartkops estuaries are $46.9 \%$ and $41 \%$ respectively (Fig. 6). This would indicate a more effective direct utilisation of primary producer products in the Ems estuary, which is also reflected in its low detrivory:herbivory ratio, i.e. the ratio between detrital consumption (uptake from suspended and sediment POC) and direct grazing on primary producers (see Table 1). The geometric-mean trophic efficiences range from $4.02 \%$ in the Swartkops to $12.49 \%$ in the Ems estuary (see Table 4). The Ythan and Kromme estuaries have very similar efficiencies of 6.64 and $6.02 \%$ respectively. Estuarine systems thus appear to differ in their trophic efficiencies.

\section{Structure and magnitude of cycling}

The cycling of material and energy in natural ecosystems is generally considered to be an important process in ecosystem function (Odum 1969), which contributes to their autonomous behaviour (Ulanowicz 1986). Cycling in ecosystems occurs through a number of cycles of different path lengths. Short cycles are usually indicative of fast cycling rates and longer path lengths of slower rates (Baird \& Ulanowicz 1989). Three aspects of cycling are discussed in this paper: (i) the number of cycles and their distributions against cycle lengths; (ii) the Finn cycling index (FCI), and (iii) the average path length for each system. Networks of the cycled flows for each system are illustrated in Figs. 6 to 9 . The cycled flows (given in $\mathrm{mg} \mathrm{C} \mathrm{m} \mathrm{C}^{-2} \mathrm{~d}^{-1}$ in the diagrams) reflect the amount of compartmental throughput that returns to that compartment after travelling the indicated loop. The number of cycles per nexus and the total number of cycles in each system are given in Table $3 \mathrm{~A}$ and the amount of cycled flow over various path lengths in Table 3B. The number of cycles ranges from 26 in the Ems estuary to 14 in the Kromme estuary. Of importance is the distribution of 


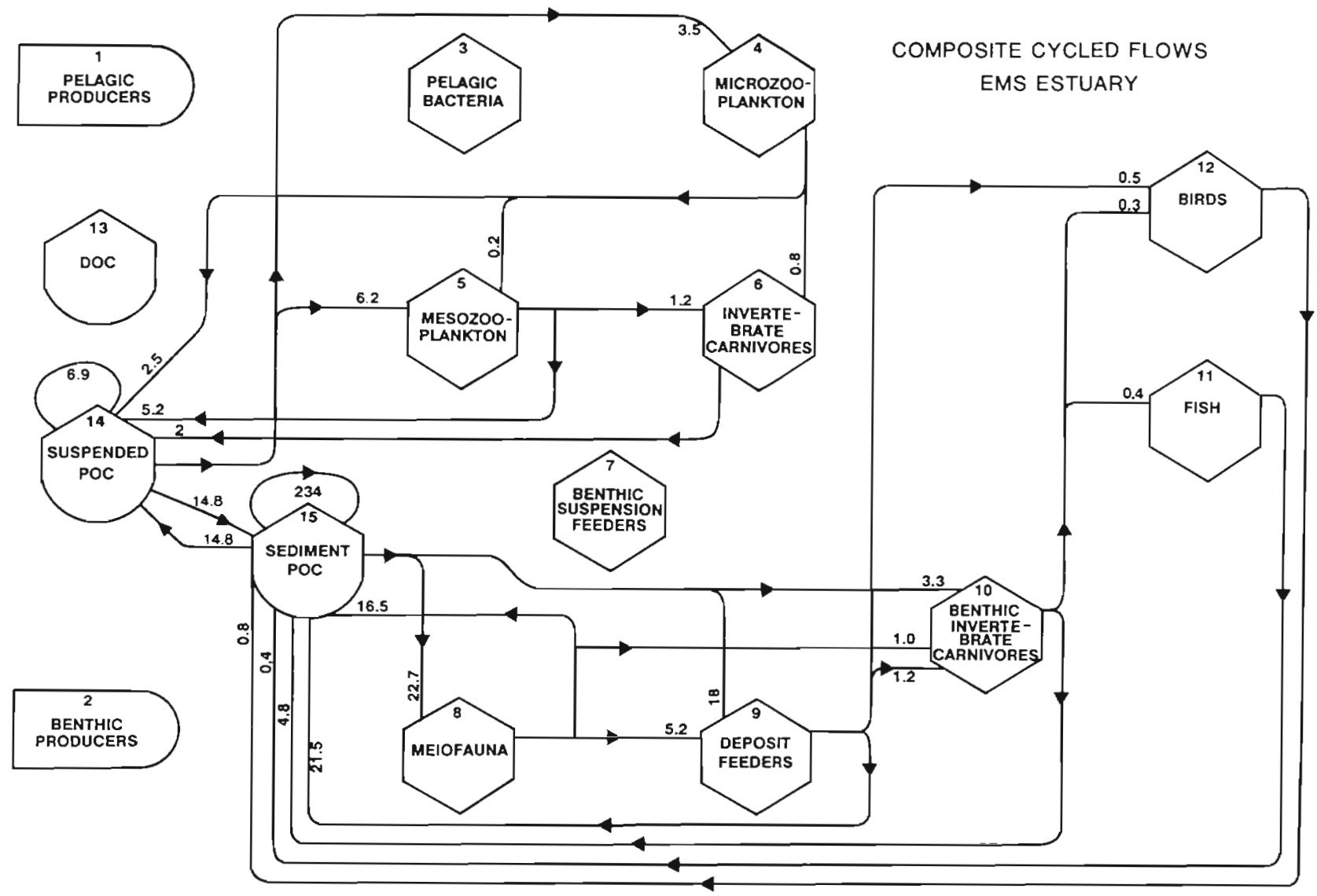

Fig. 6. Composite cycling of carbon in the Ems estuary. Units of flow and compartment numbers are the same as in Fig. 1. Feed back loops in Compartments $14 \& 15$ indicate cycling within the compartment between bacteria and POC
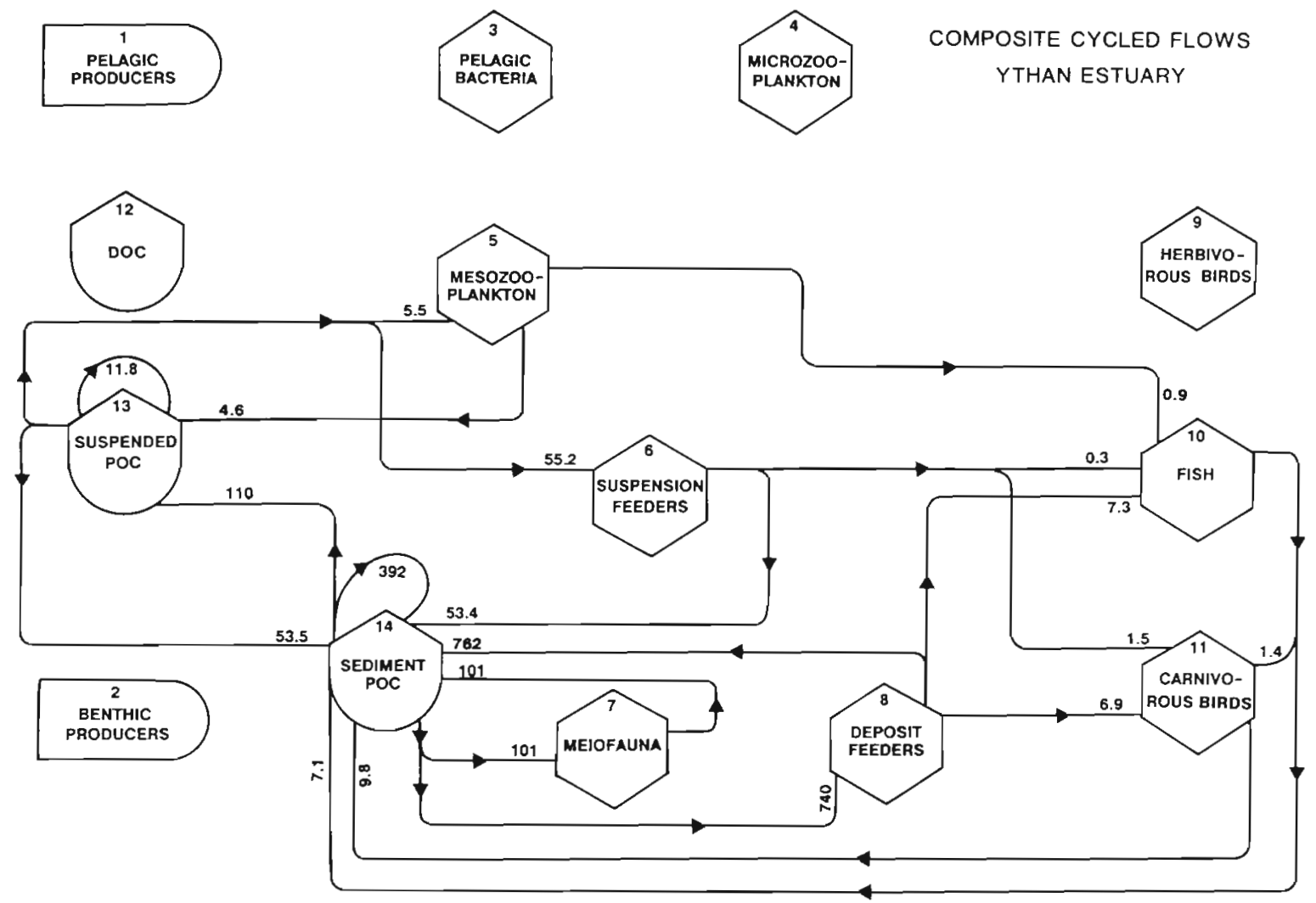

Fig. 7. Composite cycling of carbon in the Ythan estuary. Units of flow and compartment numbers are the same as in Fig. 2. Feed back loops in Compartments $13 \& 14$ indicate cycling within the compartment between bacteria and POC 


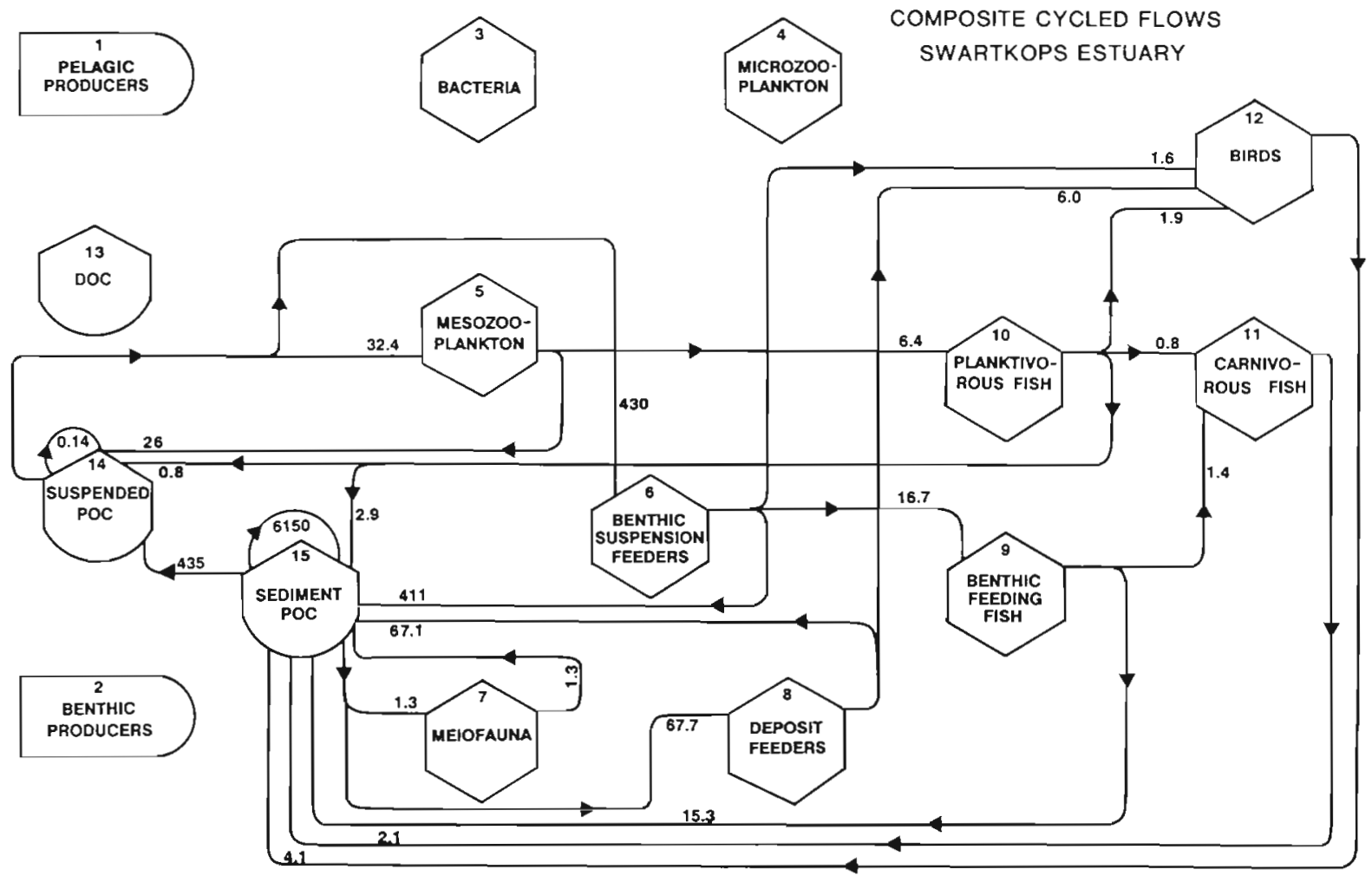

Fig. 8. Composite cycling of carbon in the Swartkops estuary. Units of flow and compartment numbers are the same as in Fig. 3. Feed back loops in Compartments $14 \& 15$ indicate cycling within the compartment between bacteria and POC
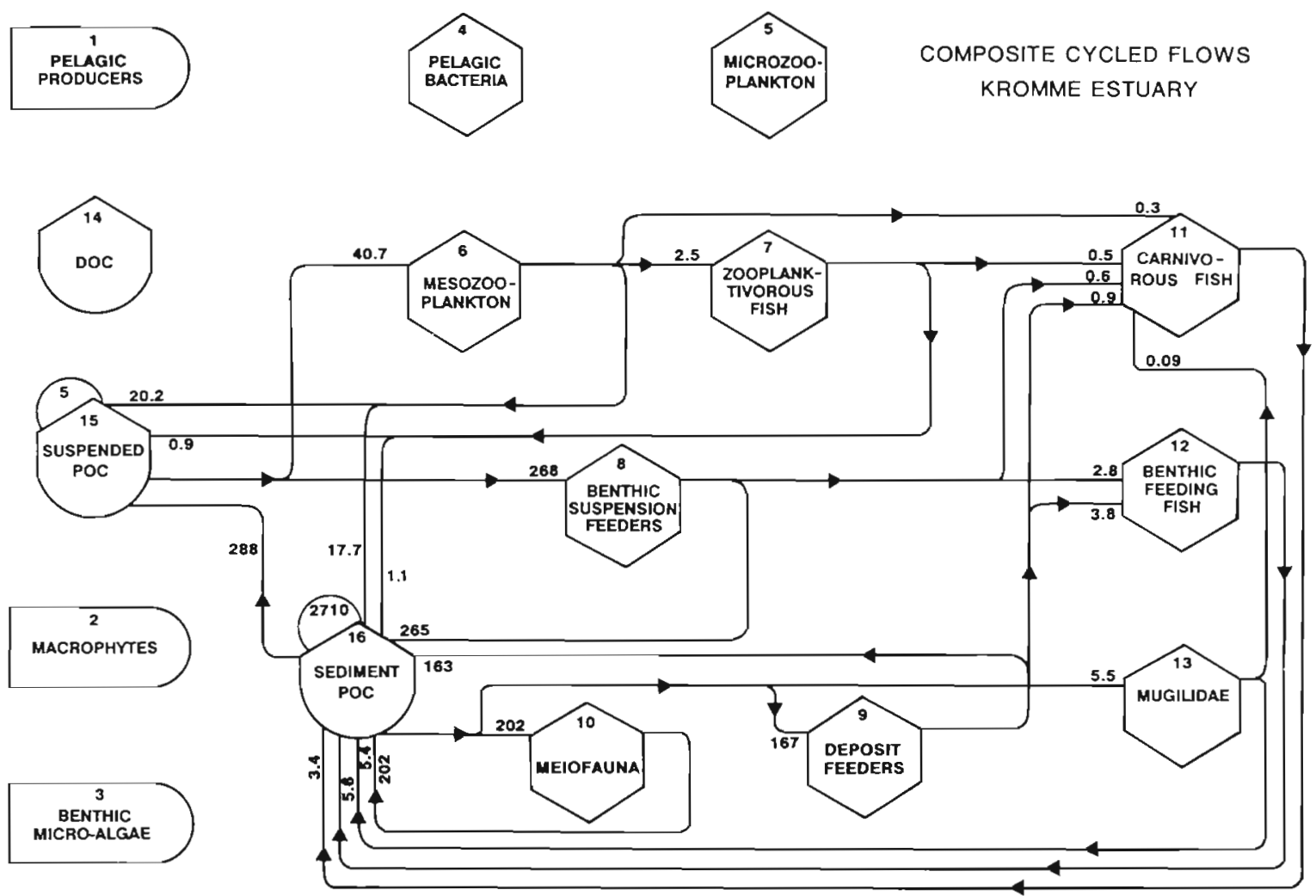

Fig. 9. Composite cycling of carbon in the Kromme estuary. Units of flow and compartment numbers are the same as in Fig. 4. Feed back loops in Compartments 15 \& 16 indicate cycling within the compartment between bacteria and POC 
Table 3. Cycle distributions

\begin{tabular}{|c|c|c|c|c|}
\hline \multicolumn{5}{|c|}{ A. Distribution (\%) of cycles per nexus } \\
\hline Cycles nexus $^{-1}$ & Ythan & Swartkops & Kromme & Ems \\
\hline 1 & 60 & 100 & 89 & 34 \\
\hline 2 & 40 & 0 & 11 & 23 \\
\hline 3 & 0 & 0 & 0 & 12 \\
\hline 4 & 0 & 0 & 0 & 31 \\
\hline \multicolumn{5}{|c|}{$\begin{array}{l}\text { B. Percent of cycled flow through loops of various path } \\
\text { lengths }\end{array}$} \\
\hline Path length & Ythan & Swartkops & Kromme & Ems \\
\hline 1 & 16.9 & 80.0 & 61.9 & 61.8 \\
\hline 2 & 74.0 & 2.2 & 17.8 & 30.0 \\
\hline 3 & 8.3 & 16.1 & 19.7 & 7.4 \\
\hline 4 & 0.7 & 1.0 & 0.5 & 0.6 \\
\hline 5 & 0.01 & 0.3 & 0.1 & 0.2 \\
\hline $\begin{array}{l}\text { Total cycled flow } \\
\left(\mathrm{mg} \mathrm{C}^{-2} \mathrm{~d}^{-1}\right)\end{array}$ & 2389 & 7679 & 4378 & 390 \\
\hline
\end{tabular}

Cycles per nexus and the amount of cyled flow over various path lengths, as shown in Table $3 \mathrm{~A} \& \mathrm{~B}$. The results show that all of the cycling in the Swartkops estuary occurs through single cycle nexuses (Table $3 \mathrm{~A}$ ) and that $80 \%$ of the cycled flow is via short and fast loops involving mainly bacteria and sediment particulate organic material (Table 3B, Fig. 8). The Ems estuary, on the other hand, shows a more even distribution of cycles per nexus (Table $3 \mathrm{~A}$ ) and cycles about $38 \%$ of its throughput via longer and slower loops. In the Kromme and Ythan estuaries about 40 and $83 \%$ of their activity, respectively, is devoted to the recycling of material via longer path lengths (Table 3B). FCls ranged from $25.5 \%$ in the Ythan, with those of the Kromme and Ems estuaries slightly higher at 25.9 and $30.0 \%$ respectively, to $43.8 \%$ in the Swartkops estuary (Table 4). The APL for 2 of the estuaries, the Ythan and the Kromme, are 2.86 and 2.38 respectively, while those of the Swartkops and Ems estuaries are longer at 3.95 and 3.42 respectively (Table 4 ). This means that a unit of carbon will be transferred at least 1 step more in the latter 2 estuaries where it thus has a slightly longer residence time. In terms of cycle distributions (Table $3 A \& B$ ), the FCI and the APL, it would thus appear that the mildly polluted Swartkops estuary shows cycle characteristics slightly different from the other 3 systems. It recycles a relatively large proportion $(43.8 \%)$ of its total flows in short cycles and has a high system APL value of 3.95. A large proportion of material is thus retained within the system, and retention takes place over a few short recycling circuits within the system. The high FCI thus suggests a relatively simple cycling structure. The cycle distributions, FCIs and APLs in the other systems are very similar. The Kromme estuary, which is the most pristine of the 4 systems, shows a more even distribution of cycled flows through different path lengths, although its $\mathrm{FCI}$ and APL are in the same order as the other estuaries. The composite cycling structure of each estuary (Figs. 6 to 9) shows that the topologies of the cycling structure of the Ythan (Fig. 7), the Swartkops (Fig. 8), and the Kromme (Fig. 9) are very similar. In these systems virtually all living compartments, with the exception of pelagic bacteria and microzooplankton, participate in the recycling of material through the suspended and sediment POC pools. A common feature of the estuaries is the resuspension of sedimentary particulate material, which is then cycled through the suspended POC compartment to other components such as meso-

Table 4. Indices of system organization derived from network analysis

\begin{tabular}{|c|c|c|c|c|}
\hline Index & Ythan & Swartkops & Kromme & Ems \\
\hline Total systems throughput ( $T, \operatorname{mg} C \mathrm{~m}^{-2} \mathrm{~d}^{-1}$ ) & 9350 & 17541 & 16879 & 1298 \\
\hline Average path length (APL) & 2.86 & 3.95 & 2.38 & 3.42 \\
\hline Finn cycling index $(\mathrm{FCl}, \%)$ & 25.5 & 43.8 & 25.9 & 30.0 \\
\hline Number of cycles & 15.1 & 14.6 & 19 & 26 \\
\hline Trophic efficiency (geometric mean, \%) & 6.64 & 4.02 & 6.02 & 12.49 \\
\hline Development capacity ( $C$, mg $C_{i}$ bits $)$ & 39264 & 62652 & 59422 & 6085 \\
\hline Ascendancy ( $A$, mg $C_{i}$ bits) & 13511 & 17565 & 20022 & 2327 \\
\hline Redundancy $\left(R\right.$, mg $C_{i}$ bits $)$ & 13206 & 22517 & 20183 & 2210 \\
\hline Relative acendancy $(A / C, \%)$ & 34.4 & 28.0 & 33.7 & 38.3 \\
\hline Internal capacity $\left(C_{i}\right.$, mg $C_{\text {; }}$ bits $)$ & 19950 & 32359 & 29880 & 3537 \\
\hline Internal acendancy $\left(A_{1}, \mathrm{mg} C_{i}\right.$ bits $)$ & 6744 & 9842 & 8597 & 1327 \\
\hline Internal relative ascendancy $\left(A_{1} / C_{1} \%\right)$ & 33.8 & 30.4 & 29.4 & 37.5 \\
\hline Flow diversity $(C / T)$ & 4.1 & 3.6 & 3.5 & 4.7 \\
\hline
\end{tabular}


zooplankton and benthic suspension feeders (Figs. 7 to 9). This process appears to be characteristic of tidal estuaries with constricted inlets and relatively fast tidal currents in excess of $1 \mathrm{~m} \mathrm{~s}^{-1}$ (Uncles et al. 1990), features common to the Ythan, Kromme and Swartkops estuaries. The Ems estuary, on the other hand, exhibits 2 separate cycling structures, one in the water column. and one benthic-pelagic cycle. Benthic suspension feeders (Compartment 7) do not engage in any cycling and serve as a link between the pelagic and benthic domains (Fig. 6). There is, however, a link between the cycling structures of the 2 domains, namely between the sediment and suspended POC compartments, which is ascribed to the resuspension and deposition of organic material (De Jonge 1985).

\section{System properties}

The global measures of systems organization of each of the 4 estuaries are given in Table 4 . The development capacity $(C)$, total throughput $(T)$, ascendancy $(A)$ and redundancy $(R)$ of the Swartkops and Kromme estuaries are of the same order but much higher than that of the Ythan and the Ems estuaries. The relative ascendancy $(A / C)$, a dimensionless ratio that excludes the influence of $T$ and is a suitable index for comparing different ecosystems (Mann et al. 1989, Baird et al. 1991), is the highest for the Ems estuary (38.2\%), 34.4 and $33.7 \%$ for the Ythan and Kromme estuaries respectively, and the lowest for the Swartkops estuary $(28 \%$ ) (see Table 4 ). Also given in Table 4 are values for the internal capacity $\left(C_{1}\right)$, the internal ascendancy $\left(A_{1}\right)$ and the normalized internal ascendancy ratio $\left(C_{1} / A_{i}\right)$. This ratio remains approximately the same as the relative ascendancy ratio $(A / C)$ for all the systems. It increases slightly by $2.4 \%$ in the Swartkops and $0.7 \%$ in the Ems estuaries, but decreases by 0.6 and $4.3 \%$ in the Ythan and Kromme estuaries respectively.

\section{DISCUSSION}

Interest in comparative ecology and in the comparison of ecosystems and ecosystem attributes appears to be growing (Nixon 1988, Baird et al. 1991, Downing 1991, Heal \& Grime 1991, Peters et al. 1991, Strayer 1991). In this context network analysis of the fluxes of complex foodwebs is an important tool in the analysis and comparison of different ecosystems (Mann et al. 1989). Baird et al. (1991), for example, compared 6 marine ecosystems worldwide using the results from network analysis. One of their conclusions is that contrary to current views, the aggregate amount of cycling is not necessarily an indication of maturity but rather of stress. In this paper we specifically addressed the trophic structure and cycling in 4 estuarine systems. Although estuaries all exhibit some common characteristics such as the mixing of fresh and seawater, their dependence on tidal energy, etc., the results presented here allowed the identification of similarities and differences between them which are not superficially recognizable. Two of the 4 estuaries discussed occur in temperate zones in the Southern Hemisphere 132 to $34^{\circ} \mathrm{S}$ ) and 2 in the cooler regions of the Northern Hemisphere $\left(53\right.$ to $57^{\circ} \mathrm{N}$ ). Seasonal fluctuations in most of the benthic (autotrophic and heterotrophic) communities are more pronounced in the Ythan (Baird \& Milne 1981) and Ems estuaries (Anon. 1985), where maximum biomass and production occurs during the warmer summer months. In the temperate estuaries (Kromme and Swartkops), however, production and biomass fluctuate within a relatively narrow range throughout the year (Pierce 1983, Hanekom \& Baird 1988). All 4 estuaries are relatively young in geological age; they owe their present configuration, morphology and sediment fill to worldwide sea level fluctuations over the past $12000 \mathrm{yr}$. Although the more recent estuarine deposits cover a wide variety of beach, older estuarine and fluvial sediments, the youngest deposits and their associated biota are essentially estuarine. The systems differ in physical size, tidal prism and fresh water volumes, and in some abiotic attributes such as temperature, salinity and nutrient loads However, they all exhibit similar ecological processes typical of estuarine ecosystems, which form the basis of this comparative study. Direct utilisation of primary produced carbon, measured as the NPP efficiency, varies significantly between the estuaries. This efficiency is exceptionally high in the Ems estuary (98\%), and much lower in the Swartkops (38\%) In the Ythan and Kromme estuaries, however, these efficiencies are even lower ( $10.5 \%$ and $9.2 \%$ respectively). There appears to be some correlation between NPP efficiencies and the detrivory : herbivory $(\mathrm{D}: \mathrm{H})$ ratio in the 4 estuaries. High $\mathrm{D} \cdot \mathrm{H}$ ratios coupled with low NPP efficiencies were observed in the Ythan and Kromme estuaries, indicating their reliance on detritus and its recycling. The low $\mathrm{D}: \mathrm{H}$ ratios and high NPP efficiencies observed in the Swartkops and Ems estuaries (Table 1) on the other hand suggest a greater diversity of resource utilization in these 2 estuaries. From the cycling analysis it is clear that the FCI and APL values of the mildly polluted Swartkops estuary are the highest (Table 4). It has been suggested by Ulanowicz (1984) that the greater the diversity of nexuses containing longer cycles, the less stress there is on the system, and that the proportion of cycling increases in more stressed systems. The combination of relatively high FCI and APL values, and the frequency of short cycles, 
lend support to the hypothesis that the Swartkops estuary is indeed more stressed than the other estuaries examined. Longer cycles are found in the Ems, Ythan and Kromme estuaries, and a greater amount of material is cycled through longer path lengths $(>2)$ when compared with the Swartkops estuary. In all estuaries, with the exception of the Ems, the cycled flows are predominantly through the sediment pools, and virtually all living components are involved in the cycling process. The Ems is the only system which exhibits a pelagic (or water column) cycle structure which is separate from benthic cycling. Benthic suspension feeders in the Ems estuary seem to occupy an important position since they do not participate in cycling, but act as a link between the pelagic and benthic domains. The same phenomenon has been observed in the cycling structure of the Chesapeake Bay (Baird \& Ulanowicz 1989). The difference between the cycling structure of the Ems and those of the other 3 estuaries can mainly be ascribed to the resuspension of sediment POC back into the water column from where it is taken up by filter feeders. Should this physical process also occur in the Ems, then the cycling structures of all 4 estuaries will be very much the same, and will only differ in the magnitude of the amount cycled. The cycling structure in a 'pristine' system, such as the Kromme estuary, does not differ markedly from the more anthropogenically enriched Swartkops and Ythan estuaries. Neither is its FCI value higher than those of the Ems and Ythan estuaries, as one would expect from chemically unstressed systems. Due to low water column productivity (i.e. of phytoplankton) and the very high benthic primary production, the Kromme estuary appears to be very much dependent on the recycling of unutilized macroalgal production which essentially drives the system via the detritus food web.

Maturity and organization of ecosystems have been associated with a greater degree of cycling (Odum $1969)$ and high relative ascendancy $(A / C)$ ratios (Baird et al. 1991). The Swartkops estuary has a high FCl value, whilst its relative ascendancy ratio is the lowest of the 4 estuaries (Table 4 ). In this case the high aggregate amount of cycling is not necessarily an indication of system maturity, as suggested by Odum (1969), but of stress within the system as argued by Ulanowicz (1984), especially if viewed in conjunction with the low $A / C$ ratio. This inverse relation would imply that the Swartkops estuary is the most impacted system of the 4 estuaries. The difference between the FCIs and between the $A / C$ ratios of the other systems is less than in the Swartkops estuary. The cycling structures in these systems are more complex and have relatively similar $A / C$ ratios. The exception is the Ems estuary which has the highest $A / C$ ratio and also appears to have the highest trophic efficiency of $12.5 \%$. Despite its low total standing stock and development capacity, this estuary would appear to be less stressed than the others under consideration.

Another global measure to underscore this point and to compare whole systems is flow diversity, suggested by MacArthur (1955) as a measure of the capacity of a system for homeostasis. Ulanowicz (1986) scaled the flow diversity by $T$ to create a measure of the capacity of the system for development. The flow diversity is derived by using the Shannon-Weaver logarithmic measure of complexity (Shannon 1948). Small differences in the values of this index hence reflect much larger quantitative disparities. According to Ulanowicz \& Wulff (1991) the larger the flow diversity value, the more remaining ability a system has to cope with disturbances. The flow diversity values (see Table 4 ) of the Swartkops and Kromme estuaries are 3.6 and 3.5 respectively. The values for the Ythan and Ems estuaries are considerably higher ( 4.1 and 4.6 respectively) indicating that these 2 systems are less impacted than the Swartkops estuary. The low value for the Kromme estuary, a chemically unimpacted system, is unexpected. Values of the internal relative ascendancy ratios $\left(A_{\mathrm{j}} / C_{\mathrm{i}}\right)$ do not differ much from the $A / C$ ratios. It has been speculated that a large decrease in the $A_{1} / C_{\mathrm{i}}$ ratio in relation to the $A / C$ ratio could indicate a strong dependency of such systems on a few dominant external connections, as exemplified by the Chesapeake Bay and Baltic Sea (Baird et al. 1991). In the estuaries considered here, these differences are small which would point to less dependence on exogenous connections than in the case of the Chesapeake and Baltic systems. It is interesting to note that the $\mathrm{FCl}$, the $\mathrm{APL}$, the $A / C$ ratio and the mean trophic efficiency of a pristine system, such as the Kromme estuary, do not differ substantially from somewhat impacted systems such as the Ems and Ythan estuaries. This study shows that quantified flow networks of the 4 systems permits one to carry out an entire suite of comparisons. The breadth of the results yield conclusions on the relative trophic status of the communities, the structure and magnitude of cycling and on some system properties. These have illustrated subtle similarities and differences which may not superficially be recognizable.

Acknowledgements. We thank Prof. J. G. Field for his critical reading and useful comments on the manuscript. This work was supported by the University of Port Elizabeth, the Institute for Coastal Research. University of Port Elizabeth. and the Chesapeake Biological Laboratory, University of Maryland System, MD, USA.

\section{LITERATURE CITED}

Anon. (1985). Biological research Ems-Dollard estuary. Rijkswaterstaat Communications. 40:1-179

Anon. (1991). Sedimentation in the Kromme estuary: data 
report. CSIIR (Council for Scientific and Industrial Research) Report EMA-D 9108, p. 1-62

Asmus, M. L., McKellar, H. N. Jr (1989). Network analysis of the North Inlet salt-marsh ecosystem. In: Wulff, F., Field, J. G., Mann, K. H. (eds.) Network analysis in marine ecology: methods and applications. Coastal and estuarine studies 32. Springer-Verlag, Heidelberg, p. 206-217

Azam, F., Fenchel, T., Field, J. G., Gray, J. S., Meyer-Reil, L. A., Thingstad, F. (1983). The role of water column microbes in the sea. Mar. Ecol. Prog. Ser. 10: 257-263

Baird, D. (1988). Synthesis of ecological research in the Swartkops Estuary. In: Baird, D., Marais, J. F. K., Martin, A. P. (eds.) The Swartkops Estuary. Proceedings of a symposium held on 14 and 15 September, 1987 at the University of Port Elizabeth. South African National Scientific Programmes Report No. 156: 41-56

Baird, D., Hanekom, N. M., Grindley, J. R. (1986). Report No. 23, Swartkops. In: Heydorn, A. E. F., Grindley, J. R. (eds.) Estuaries of the Cape, Part II, Synopsis of available information on individual systems. CSIR Res. Report 422: 1-82

Baird, D., Marais, J. F. K., Bate, G. C. (1992). An environmental analysis for the Kromme River area to assist in the preparation of a structure plan. Institute for Coastal Research, University of Port Elizabeth, South Africa. Report No. C16: 1-56

Baird, D., Marais, J. F. K., Martin, A. P. (eds.) (1988). The Swartkops Estuary. Proceedings of a symposium held on 14 and 15 September, 1987 at the University of Port Elizabeth. South African National Scientific Programmes Report No. 156: 1-107

Baird, D., Marais, J. F. K., Wooldridge, T. (1981). The influence of a marina canal system on the ecology of the Kromme Estuary, St. Francis Bay. S. Afr. J. Zool. 16: 21-34

Baird, D., McGlade, J. M., Ulanowicz, R. E. (1991). The comparative ecology of six marine ecosystems. Phil. Trans. R. Soc. Lond. B. 333: 15-29

Baird, D., Milne, H. (1981). Energy flow in the Ythan Estuary, Aberdeenshire, Scotland. Estuar. coast. Shelf Sci. 13: $455-472$

Baird, D., Pereyra-Lago, R. (1992). Nutrient status and water quality assessment of the Marina Glades canal system, Kromme Estuary, St. Francis Bay. Water SA 18: 37-42

Baird, D., Ulanowicz, R. E. (1989). The seasonal dynamics of the Chesapeake Bay ecosystem. Ecol. Monogr. 59: 329-364

Baird, D., Winter, P. E. D. (1989). Annual flux of dissolved inorganic nutrients through a well-mixed estuary. In: Michaelis, W. (ed.) Estuarine water quality measurement: monitoring, modelling and research. Coastal and estuarine studies 36. Springer-Verlag, Heidelberg, p. 335-340

Baretta, J., Ruardij, P. (eds.) (1988). Tidal flat estuaries: simulation and analysis of the Ems Estuary. Ecological Studies 71. Springer-Verlag, Heidelberg, p. 1-353

Bickerton, I. B., Pierce, S. M. (1988). Estuaries of the Cape. In: Heydorn, A. E. F., Morant, P. D. (eds.) Part III: Synopsis of available information on individual systems. Rep. No. 33, Krom (CMS 45), Seekoei (CMS 46) and Kabeljous (CMS 47). CSIR Res. Report 432:1-109

Brylinsky, M. (1977). Release of dissolved organic matter by some marine macrophytes. Mar. Biol. 39: 213-220

De Jonge, V. N. (1988). The abiotic environment. In: Baretta, J., Ruardij, P. (eds.) Tidal flat estuaries: simulation and analysis of the Ems Estuary. Ecological studies 71. Springer-Verlag, Heidelberg, p. 14-27

Downing, J. A. (1991). Comparing apples with oranges: methods of interecosystem comparison. In: Cole, J., Lovett, G., Findlay, S. (eds.) Comparative analyses of ecosystems: patterns, mechanisms and theories. Springer-Verlag. New York, p. 24-45

Ducklow, H. W. (1983). Production and fate of bacteria in the oceans. BioSci. 33: 494-501

Ducklow, H. W., Fasham, M. J R., Vezina, A. F. (1989). Derivation and analysis of flow networks for open ocean plankton systems. In: Wulff, F., Field, J. G., Mann, K. H. (eds.) Network analysis in marine ecology: methods and applications. Coastal and estuarine studies 32. SpringerVerlag, Heidelberg, p. 159-205

Emmerson, W. D. (1985). The nutrient status of the Swartkops River estuary, eastern Cape. Water SA 11: 189-198

Emmerson, W. D., Erasmus, T (1987). The nutrient status of the Kromme River estuary, South Africa. Hydrobiologia 36: $479-488$

Field, J. G., Moloney, C. L., Attwood, C. G. (1989a). Network analysis of simulated succession after an upwelling event. In: Wulff, F. Field, J. G., Mann, K. H. (eds.) Network analysis in marine ecology: methods and applications. Coastal and estuarine studies 32 . Springer-Verlag, Heidelberg, p. $132-158$

Field, J. G., Wulff, F., Mann, K. H. (1989b). The need to analyze ecological networks. In: Wulff, F., Field, J. G., Mann, K. H. (eds.) Network analysis in marine ecology: methods and applications. Coastal and estuarine studies 32 . Springer-Verlag, Heidelberg, p. 3-12

Findlay, S., Carlough, L., Crocker, M. T., Gill, H. K., Meyer, J. L., Smith, P. J. (1986). Bacterial growth on macrophyte leachate and fate of bacterial production. Limnol. Oceanogr. 31: 1335-1341

Finn, J. T (1976). Measures of ecosystem structure and function derived from analysis of flows. J. theoret. Biol. 56: $363-380$

Fogg, G. E., Nalewajko, C., Watt, W. D. (1965). Extra-cellular products of phyto-plankton photosynthesis. Proc. R. Soc. Lond. B. 162: 517-534

Fromme, G. A. W., Badenhorst, P. (1987). The dynamics of the estuaries of St. Francis Bay (Kromme, Seekoei and Kabeljous). CSIR Report T/SEA 8707.1-39

Hanekom, N. M. (1980). A study of two thalassinid prowns in the non-Spartina regions of the Swartkops estuary. Ph.D. thesis, University of Port Elizabeth

Hanekom, N. M. (1982). An ecological study of the Zostera beds in the Kromme estuary. University of Port Elizabeth Report Series. Report No. 18, p. 205

Hanekom, N., Baird, D. (1984). Fish community structures in Zostera and non-Zostera regions of the Kromme Estuary, St. Francis Bay. S. Afr. J. Zool. 19: 295-301

Hanekom, N., Baird, D. (1988). Distribution and variations in the seasonal biomass of eelgrass Zostera capensis in the Kromme Estuary, St. Francis Bay, South Africa. S. Afr. J mar. Sci. $7: 51-59$

Hanekom, N. M., Baird, D. (1992). Growth, production and consumption of the thalassinid prawn Upogebia africana (Ortmann) in the Swartkops estuary. S. Afr. J. Zool. 27 : $130-139$

Hanekom, N. M., Baird, D., Erasmus, T (1988). A quantitative study to assess standing biomass of macrobenthos in soft substrata of the Swartkops Estuary, South Africa. S. A.fr. J. mar. Sci. 6: 163-174

Hannon, B. (1973). The structure of ecosystems. J. theoret. Biol. 41: 535-546

Hatcher, B. G., Chapman, A. R. O., Mann, K. H. (1977). An annual carbon budget for the kelp Laminaria longicuris. Mar. Biol. 44: 85-96

Heal, O. W., Grime, J. P. (1991). Comparative analysis of ecosystems: past lessons and future directions. In: Cole, J., 
Lovett, G., Findlay, S. (eds.) Comparative analyses of ecosystems: patterns, mechanisms and theories. SpringerVerlag, New York, p. 7-23

Hecht, T. (1973). The ecology of the Kromme estuary with special reference to Sesarma catenata. M.Sc. thesis, University of Port Elizabeth, p. 150

Heymans, S., Baird, D. (1991). Energy flow model of the Kromme estuary, St. Francis Bay. Paper presented at the symposium of the Zoological Society of southern Africa. Stellenbosch University, Stellenbosch, July 1991

Heymans, S., Baird, D. (1992). Preliminary network analysis of the Kromme Estuary, St. Francis Bay. Paper presented at a Conference on Aquatic Ecosystems. Cape Town University, Rondebosch, July 1992

Hilmer, T., Talbot, M. M. B., Bate, G. C. (1988). A synthesis of recent botanical research in the Swartkops Estuary. In: Baird, D., Marais, J. F. K., Martin, A. P. (eds.) The Swartkops Estuary. Proceedings of a symposium held on 14 and 15 September, 1987 at the University of Port Elizabeth. South African National Scientific Programmes Report No. 156: 25-40

Kay, J. J., Graham, L. A., Ulanowicz, R. E. (1989). A detailed guide to network analysis. In: Wulff, F., Field, J. G., Mann, K. H. (eds.) Network analysis in marine ecology: methods and applications. Coastal and estuarine studies 32 . Springer-Verlag, Heidelberg, p. 15-61

Leontief, W. W. (1951). The structure of the American economy, 1919-1939, 2nd edn. Oxford Univ. Press, New York

Linley, E. A. S., Newell, R. C., Bosma, S. A. (1981). Heterotrophic utilization of microalgae released during fragmentation of kelp (Eklonia maxima and Laminaria pallida). I. Development of microbial communities associated with the degradation of kelp mucilage. Mar. Ecol. Prog. Ser. $4: 31-41$

Longhurst, A. R. (1984). The importance of measuring rates and fluxes in marine ecosystems. In: Fasham, M. J. R. (ed.) Flows of energy and material in marine ecosystems: theory and practice. Plenum Press, New York, p. 1-32

Lord, D. A., Thompson, G. A. (1988). The Swartkops Estuary: pollution status. In: Baird, D., Marais, J. F. K., Martin, A. P. (eds.) The Swartkops Estuary. Proceedings of a symposium held on 14 and 15 September, 1987 at the University of Port Elizabeth. South African National Scientific Programmes Report No. 156: 16-24

MacArthur, R. H. (1955). Fluctuations of animal populations and a measure of cormmunity stability. Ecology 36 : $533-536$

Mann, K. H., Field, J. G., Wulff, F. (1989). Network analysis in marine ecology: an assessment. In: Wulf, F., Field, J. G., Mann, K. H. (eds.) Network analysis in marine ecology: methods and applications. Coastal and estuarine studies 32. Springer-Verlag, Heidelberg, p. 259-282

Marais, J. F. K (1983). Seasonal abundance, distribution and catch per unit effort in the Kromme estuary, South Africa. S. Afr. J. Zool. 18: 96-102

Marais, J. F. K. (1984). Feeding ecology of major carnivorous fish from four Eastern Cape Estuaries. S. Afr. J. Zool. 19: $210-223$

Marais, J. F. K. (1987). Some factors that influence fish abundance in South African estuaries. S. Afr. J. mar. Sci. 6: $67-77$

Marais, J. F. K., Baird, D. (1980a). Analysis of anglers catch data from the Swartkops estuary. S. Afr. J. Zool. 15: 61-65

Marais, J. F. K., Baird, D. (1980b). Seasonal abundance, distribution and catch per unit of effort of fishes in the Swartkops estuary. S. Afr. J. Zool. 15: 66-71

Martin, A. P. (1991). Feeding ecology of birds in the
Swartkops Estuary. Ph.D. thesis, University of Port Elizabeth, p. 267

Martin, A. P., Baird, D. (1987). Seasonal abundance and distribution of birds on the Swartkops Estuary, Port Elizabeth. Ostrich 58: 122-134

Mason, H., Marais, J. F. K. (1975). Stomach content analysis of mullet from the Swartkops Estuary. Zool. afr. 1: 203-208

Melville-Smith, R., Baird, D. (1980). Abundance, distribution and species composition of fish larvae in the Swartkops Estuary. S. Afr. J. Zool. 15: 72-78

Nixon, S. W. (ed.) (1988). Comparative ecology of fresh water and marine ecosystems. Limnol. Oceanogr. 33: 649-1025

Odum, E. P. (1971). The strategy of ecosystem development. Science 164: $262-270$

Odum, H. T (1948). Environment, power and society. John Wiley and Sons, New York, p. 331

Peters, R. H., Armesto, J. J., Boeken, B., Cole, J. J., Driscoll, C. T., Duarte, C. M., Frost, T. M., Grime, J. P., Kolasa, J., Prepas, E., Sperules, W. G. (1991). On the relevance of comparitive ecology to the larger field of ecology. In: Cole, J., Lovett, G., Findlay, S. (eds.) Comparative analyses of ecosystems: patterns, mechanisms and theories. SpringerVerlag, New York, p. 46-63

Pierce, S. M. (1983). Estimation of the non-seasonal production of Spartina maritima (Curtis) Fernald in a South African estuary. Estuar coast. Shelf Sci. 16: 241-254

Raffaelli, D. (1992). Conservation of Scottish estuaries. Proceed. R. Soc. Edinburgh 100B: 55-76

Reddering, J. S. V., Esterhuysen, K. (1981). The sedimentary ecology of the Swartkops estuary. Department of Geology, University of Port Elizabeth, Research on Sedimentation in Estuaries Report No. 1

Shannon, C. E. (1948). A mathematical theory of communication. Bell System Tech. J. 27: 379-423

Sieburth, J. McN., Jensen, A. (1969). Studies on algal substances in the sea. II. The formation of gelgstolf (humic material) by exudates of Phaeophyta. J. exp. mar. Biol. Ecol. 3: $257-289$

Strayer, D. L. (1991). Comparative ecology and undiscovered public knowledge. In: Cole, J., Lovelt, G., Findlay, S. (eds.) Comparative analyses of ecosystems: patterns, mechanisms and theories. Springer-Verlag, New York, p. 3-6

Talbot, M. M. J.-F., Baird, D. (1985). Feeding of the estuarine round herring Gilchrestella aestuarius (G\&T) (Stolephoridae). J. exp. mar. Biol. Ecol. 87: 199-214

Ulanowicz, R. E. (1983). Identifying the structure of cycling in ecosystems. Math. Biosci. 65: 219-237

Ulanowicz, R. E. (1984). Community measures of marine food networks and their possible applications. In: Fasham, M. J. R. (ed.) Flows of energy and materials in marine ecosystems. Plenum Press, New York, p. 23-47

Ulanowicz, R. E. (1986). Growth and development: ecosystems phenomenology. Springer-Verlag, New York

Ulanowicz, R. E. Mann, K. H. (1981). Ecosystems under stress. In: Platt, T., Mann, K. H., Ulanowicz, R. E. (eds.) Mathematical models in biological oceanography. The UNESCO Press, Paris, p. 133-137

Ulanowicz, R. E., Norden, J. S. (1990). Symmetrical overhead in flow networks. Int. J. Systems Sci. 21. 429-437

Ulanowicz, R. E., Platt, T (eds.) (1985). Ecosystem theory for biological oceanography. Can. Bull. Fish. Aquat. Sci. 213: $1-260$

Ulanowicz, R. E., Wulff, F. (1991). Comparing ecosystem structures: the Chesapeake Bay and the Baltic Sea. In: Cole, J., Lovett, G., Findlay, S. (eds.) Comparative analyses of ecosystems: patterns, mechanisms and theories. Springer-Verlag, Heidelberg, p. 140-166 
Uncles, R. J., Baird, D., Reddering, J S. V (1990). Tidal dynamics and sediment bed-type of an estuary with a con stricted mouth. In: Huatong, W., Jingyoung, W., Hua, D. (eds.) Physics of shallow seas. China Ocean Press, Beijing, p. $199-209$

Valiela, I. (1584). Marine ecological processes. SpringerVerlag, New York

Vegter, F, de Visscher, P. R. M. (1984). Extracellular release by phytoplankton during photosynthesis in Lake Grevelingen (SW, Netherlands). Neth. J. Sea Res. 18: 260-270

Warwick, R. M., Radford, P. J. (1989). Analysis of the flow network in an estuarine benthic community. In: Wulff, F.,

This article was submitted to the editor
Field, J. G., Mann, K. H. (eds.) Network analysis in marine ecology: methods and applications. Coastal and estuarine studies 32. Springer-Verlag, Heidelberg, p. 220-231

Wiebe, W. J., Smith, D. F. (1977). Direct measurement of dissolved organic carbon release by phytoplankton and incorporation by micro-heterotrophs. Mar. Biol. 42: 213-223

Winter, P. E. D., Baird, D. (1991). The exchange of phosphate between the Swartkops estuary and Algoa Bay. S. Afr. J. Sci. 87. 192-197

Wulff, F., Field, J. G., Mann, K. H. (eds.) (1989). Network analysis in marine ecology: methods and applications. Coastal and estuarine studies 32. Springer-Verlag, Heidelberg

Manuscript first received: September 16, 1992

Revised version accepted: April 15, 1993 